\title{
Public Policy Design and Implementation in Slovenia ${ }^{1}$
}

\author{
Jernej Mencinger \\ University of Ljubljana, Faculty of Administration, Slovenia \\ jernej.mencinger@fu.uni-lj.si \\ Polonca Kovač \\ University of Ljubljana, Faculty of Administration, Slovenia \\ polonca.kovac@fu.uni-lj.si \\ Tina Jukić \\ University of Ljubljana, Faculty of Administration, Slovenia \\ tina.jukic@fu.uni-lj.si \\ Mirko Vintar \\ University of Ljubljana, Faculty of Administration, Slovenia \\ mirko.vintar@fu.uni-lj.si
}

\section{ABSTRACT}

Public policy design and implementation is a complex process, and so decision makers try to monitor all of the policy lifecycle stages in a particular policy domain. However, the question of coherent integration of various policy activities arises, including agenda-setting, ex-ante evaluation, formulation, decision-making, implementation, ex-post evaluation of individual policies, sector-specific ones, and even horizontal ones. Therefore, it is important to investigate and understand the reasons why an individual country, such as Slovenia, does not exploit all potential aspects of carrying out policy activities in a systematic and coherent manner. This article explores and analyzes Slovenian practice in policy design based on an in-depth empirical study among key public policyholders and decision makers. Furthermore, the authors identify the key success factors that facilitate or inhibit the development and progress of public policies, programs, and projects (PPPP) in Slovenia. The key findings indicate a particular lack of a professional policy unit to monitor the process holistically and the absence of ex-post evaluation. A need for a systemic solution in public policy design is established, which would merge different authorities' efforts, epistemic communities, and the public in developing a structural multilevel model for good public governance.

1 Corresponding author:dr. Jernej Mencinger, jernej.mencinger@fu.uni-lj.si.This article is a result of the project Development of the model for monitoring and evaluation of development programmes and projects in public sector, No J5-7557. The authors acknowledge the project was financially supported by the Slovenian Research Agency. More: http://atena-kronos.si/en/. 
Key words: public policy, cycle, evaluation, public administration, good governance, Slovenia.

\section{$J E L: Z 18$}

\section{Introduction}

In many countries, effective shaping of public policies, programs, and projects (PPPP), let alone their implementation and monitoring, institutionalization, and evaluation, is one of the weakest points of public governance. In this regard, Slovenia is no exception because it faces many difficulties in formatting development goals, public policies, and programs in all key areas of public service performance and authority. The European Commission constantly issues warnings about delays in implementing directives in various areas, such as in social policy, transport, energy efficiency, environment, and financial services. This is represented by the index of European directives' implementation into legislation (i.e., the transposition deficit), for Slovenia totaling $1.7 \%$ in 2016, exceeding the EU target level (1.0\%) and average (1.5\%; EC, 2017). Nevertheless, agenda-setting, formulating, decision-making, implementing, and evaluating public policies is undoubtedly a complex process. Therefore, it is difficult to identify the effects of PPPP, either upwards in relation to European development policies, trends, and directives, and even more so downwards from concrete public politics towards implementation of programs and projects. Development in the public domain cannot be judged only through the eyes of the economy because it encompasses a set of different public policies in the country and is exposed to a number of interests, constraints, and guiding principles that often even conflict. It is the aspiration of every developed country to harmonize different public policies by using balanced and sustainable approaches (von Raggamby and Rubik 2012).

Policy analysis and associated stages in the policy cycle are well elaborated in theory. The main aim of this research is to identify, elaborate, and explore the key success factors that influence the effectiveness of PPPP in Slovenian public administration when looking at the entire policy cycle process of PPPP. Hence, we explore the extent to which strategic, institutional, regulatory, financial, and organizational aspects influence the development and progress of PPPP in Slovenia. These aspects are scrutinized using structured and semi-structured interviews with policymakers from various public policies. The methodological approach selected makes it possible to present the views of policymakers on the importance of 1) strategic policy cycle activities in the long term, 2) institutionalization of policy design within the government sector, and 3) the regulatory, 4) financial, 5) methodological, and 6) organizational perspective on the functioning and development of PPPP in Slovenia. In this regard, we conducted twenty-two interviews with selected senior officials that had obtained valuable experience as policymakers in various fields of PPPP.

The main contribution of this research is to validate how those dimensions/ factors of PPPP design are perceived and considered by policymakers, and 
whether neglecting them may have detrimental effects on carrying out PPPP. To our knowledge, our study is the first attempt to elaborate the PPPP design in Slovenia in such a comprehensive and systematic way by addressing a number of key success factors and/or perspectives. Moreover, most studies conducted in this field focus on each policy cycle stage individually. Thus, the information obtained helps answer the following key questions of this research: 1) whether there is a systematic and comprehensive approach in PPPP designing throughout the entire policy cycle process (i.e., agendasetting, policy formulation, decision-making, policy implementation, and policy evaluation) and 2) whether there is a distinctive politico-administrative dichotomy between stakeholders in the policy process. Both pivotal research problems are considered trough the lens of inter-related dimensions/factors, such as strategic, institutional, regulative, methodological, financial, and organizational framework in PPPP design in Slovenia. Thus, our research relies on the typical policy cycle framework to explore in functioning of the policy design framework in Slovenia. This simple and linear segmentation of the policy process into phases allows us a clearer identification of possible inconsistencies within the policy cycle stages and to what extent those factors have an influence in the development of PPPP. Moreover, the politico-administrative relation is presented to characterize an ideal structure and dynamic among stakeholders in the policy process. This illustrative governing framework is considered to distinguish between the political and administrative process in PPPP development. However, the generalization of both theoretical aspects present a limitation of our research due to some drawbacks related to the simplification and fragmentation of reality in exploring the policy cycle process and politico-administrative relations. This allows us to establish and verify the theoretical underpinnings on how these selected factors/dimension influence the functioning and develop of PPPP in Slovenia. Thus, our descriptive empirical research provides a better understanding of the policy process, focusing on the issues listed above. In this respect, we would like to establish some guidelines in order to make PPPP more predictable and manageable for policymakers throughout the entire public policy cycle.

This article is organized as follows. The first part of the article examines, summarizes, and presents the current status and findings concerning theoretical aspects of PPPP development and implementation focusing on the whole public policy cycle and politico-administrative relations. We continue by presenting the findings of an empirical analysis carried out between January and September 2017 in Slovenian public administration. The final part of the article discusses some of the most interesting findings concerning the issues raised. We conclude by listing some of the key recommendations for decision makers in Slovenia and comparable countries. 


\section{The Public Policy Cycle}

The theoretical underpinning of our comprehensive research is based on the policy cycle framework. ${ }^{2}$ Namely, the policy cycle framework allows policymakers to examine and assess the policy process according to a continuous system via subsequent stages. However, this approach has some limitations related to the simplification and fragmentation of reality in exploring the policy cycle process (see Jann and Wegrich, 2007). As highlighted by Jann and Wegrich (2007), the policy cycle description leans more towards a prescriptive and regulatory perspective in understanding the policy process. This means that an analytical and descriptive approach is less pronounced in the policy decision-making process, which to a certain degree does not resemble reality. According to current literature, the policy cycle process distinguishes five stages (agenda-setting, policy formulation, decision-making, policy implementation, and policy evaluation), which may lead to termination or modification (Howlett et al., 2003; Jann and Wegrich, 2007; Savard and Banville, 2012). This segmentation of the policy process into a linear sequence is constructed in accordance with a problem-solving model, theoretically based on rational behavior models of planning and decision-making, which are widely used in organizational theory and public administration (Jann and Wegrich, 2007). However, this division of the policy process cycle into various stages represents the most widely used analytical framework to explore the establishment of different PPPP.

The initial stage of the policy cycle process serves as a platform for identifying a public policy problem that has arisen in a society that requires attention and possible intervention by policymakers or the government. This is a crucial stage for policymakers to decide and select which public problem highlighted by the public or media should be targeted and why this is important or crucial for society. Thus, agenda-setting for public policies in principle encompasses the definition of the problem and the search for policy alternatives. Moreover, the selection and determination of the public problem and, hence, shaping agenda-setting to tackle the problem are inherently connected with a political process (see Jann and Wegrich 2007; Howlett et al., 2003; Princen, 2007; Fawzi, 2017). Policymakers should therefore explore and recognize the social and political background underlying this issue and analyze deficiencies in the current policy process. The insights gained into the policy should subsequently be used to create an agenda for the future development of public policies (UK Essays, 2013). However, the main limitation of this prelude stage before the decision-making process is which issues are listed on the agenda and which are denied or postponed. This controversy is based on the interaction between the political and democratic process (Damore et al., 2012), which may lead to a gap between theoretical assumptions and practice in society.

2 The policy cycle concept was established by Lasswell in the 1950s (see Savard and Banville, 2012; Jann and Wegrich, 2007). 
The previous stage is followed by policy formation and a decision-making process ${ }^{3}$ in the policy cycle. What actually becomes part of agenda-setting and later the subject of policy formation and the decision-making process is greatly determined by influential actors. Non-governmental stakeholders are often initiators of public policies; however, state institutions still play the main role in reformulating a public policy problem and mostly in decisionmaking; their formal position gives them the power of policymaking (Hill, 2009; Wheelan, 2011). According to Howlett et al. (2003) and Savard and Banville (2012), this stage enables policymakers to search for possible solutions to the policy problem and decide about them based on an evaluation of their impact on options for the problem and certain constraints (i.e., financial and methodological). Namely, policymakers must decide which possible solutions to the problem can be applied by considering the financial constraint of state funds. In addition, methodological constraints shape the formulation of the policy process through institutional influence (i.e., a procedure is predetermined by the regulatory framework of the government) or by the interaction and influence of various stakeholders (i.e., agents, social or interest groups, think tanks, etc.) involved in this policy process. Especially interaction and agreement among stakeholders and the government is crucial for shaping and formulating the framework of public policy development. Thus, less strict agreement between social groups and policymakers can in essence achieve a better and more innovative outcome in formatting public policies (Savard and Banville, 2012). Moreover, policy formation defines policy objectives, which leads to the constitution of government programs and projects of public policies. Research on policy formation and decision-making focuses on theory and practice. Namely, from the former perspective this stage utilizes a wide range of organizational, incremental, and institutional theories related to decisionmaking using approaches such as the public choice model and the garbage can model (defined by Cohen et al., 1972; Jann and Wegrich, 2007; Sidney, 2007).

When making decisions about policy agenda and formulating the policy process, policymakers must determine the anticipated methods and policy tools that needed to be applied for each policy program and project. The formulation of this process and definition of methods need to be outlined in line with the legislative framework, which supports PPPP design and its realization. Moreover, these accepted solutions/alternatives must include a detailed description of the process timeline and how the responsibility is shared among agents and government institutions. This articulation is followed by a decisionmaking process in which the policymakers have to decide about political and practical feasibility, acceptability, and financial repercussions. Thus, this stage of policy process is found among stakeholders in government bureaucracies, interest groups, thinks tanks, legislative government boards, and so on, which gives them immense power to decide about policy choices. In the context of the institutional and regulatory framework, different countries pursue various approaches that most often depend on 1) whether they are primarily striving

3 The distinction between policy formation and the decision-making process as separate and independent sub-stages is vague from the theoretical perspective (see Jann and Wegrich, 2007). 
for a participative democracy within a society or efficient and effective public governance, and 2) which political, legal, and cultural setting is characteristic for a certain country in terms of systems that are more regulatory determined or free market-oriented (Radaelli and De Francesco, 2007; Kovač et al., 2009; Bevir, 2011; OECD, 2015b). However, when formatting the policy process and deciding on approaches, the stakeholder should be aware of limited rationality. This implies that a particular selection of solutions and alternatives cannot provide an optimal or the most effective strategy in policy design. Thus, this must be taken into account when designing and selecting possible solutions to the policy problem (Sidney, 2007).

The subsequent independent stage is the implementation of policy decisions into reality. Namely, government decisions written in the form of legislation, directives, and strategic plans must be realized in practice. In most cases, the implementation of PPPP is one of the weakest points in the performance of various state administrations. From a theoretical perspective, the implementation of PPPP leans on established theories, such as institutional theory (Cerny, 1990; Heywood, 2000; Ostrom, 2011; Skocpol, 1997), system theory (Easton, 1953, 1965; Sabatier, 2007; Stewart and Ayres, 2001), theory of rational choice (Ostrom 1986, 1999; Buchanan and Tullock, 1962; Olson, 1965), and theory of good governance (Bang and Esmark 2009; Esmark, 2011; Kooiman, 2003). These theories define the behavior of institutions and individuals within them, which also has a major influence on the success of development programs and projects performed by them. Moreover, most studies of this stage show a divergence between theoretical expectations and how defined policy programs and projects are carried out in practice. The major role in implementing programs and projects is transferred to public servants in the state administration. Thus, the implementation of public policies depends, on the one hand, on the behavior and personality of public servants. This aspect is closely related to the organizational culture developed in government institutions, which has an impact on the implementation of the policy process through individually shaped norms in ideological and professional terms. In addition, some agencies in administration have developed their own specific rules, which influence the outcome of the policy process (e.g., following a more restrictive interpretation of rules in migration and asylum policy). On the other hand, institutional factors may play a crucial role in changing their behavior or affecting them when implementing public policy according to government agendas. In this regard, the implementation of PPPP is also influenced by other external interest groups or stakeholders (Savard and Banville, 2012). These factors can even exacerbate the gap between theoretical expectations and practical outcomes.

Currently, policymakers focus on the evaluation process, which is mostly a result of embedded rational behavior in the policy cycle process. It is obvious that the direction of policies in any public area requires continuous monitoring and evaluation of impacts, which is aimed at determining the efficiency and effectiveness of implementing measures and financial requirements. In practice, the implementation of various measures and activities that are 
an integral part of public programs and individual projects may, for various reasons, cause a deviation from the envisaged impacts. Deviations may jeopardize the effectiveness of the program and further prevent achievement of the targets set in the stage of PPPP adoption. It is therefore necessary to continuously monitor PPPP implementation, which allows timely identification of possible deviations and rapid adaptation to altered circumstances (i.e., modification of programs and projects or public policy problem redefinition, starting with agenda-setting). Thus, the evaluation stage is embedded in all policy cycle stages and not only in the final stage (Jann and Wegrich, 2007). This makes it possible to compare the achieved and expected effects of PPPP implementation according to its timing. The aim of PPPP evaluation is to identify deviations in the impacts of a selected program or project in relation to the expected impact of the pursuit of public policy. The proposed impact is defined as the difference between the impact of public policy implementation (the actual state) and the impact or the outcome in the case of a public policy's lack of action (i.e., non-intervention).

The state as the (predominant) PPPP holder should adopt better policies and regulations and is encouraged to do so by OECD programs and policies and by the EU in particular (cF. Radaelli and De Francesco, 2007; SIGMA, 2014; Kovač, 2017). In such a sense, ex-ante and ex-post evaluation are policy analysis methods intended to support the authorities in formulating, adopting, implementing, and monitoring improvements of the PPPP system in the sense of good governance. Evaluation affects the quality of policies particularly because it provides decision makers with a clear and in-depth picture of what a policy will cause when implemented, thus making the choice between political alternatives on possible decisions in the respective area easier, as shown by elaboration of the PPPP design steps. In particular, in the framework of the political-administrative process or public governance, an ex-ante evaluation should serve as a basis for the political (usually government) choice among several alternative proposals or solutions to open social problems developed by administrative professionals. Furthermore, ex-post evaluation would address the process with a feedback loop in order to implement PPPP consistently, efficiently, and effectively in long run. For such reasons, evaluation should also be considered one of the foundations for establishing political and professional accountability for adopting selected PPPP (see Schuppert, Considine, and Azfal, cited in Bevir, 2011). Hence today the authorities-either the state or others (e.g., regulatory agencies) — play a much different role than in the past. They are not superior to other social groups, but instead need to proportionally coordinate the interests in society between subsystems such as business, NGOs, and individuals. The purpose of evaluating PPPP and its redefinition is to either maintain the existing policy and measures or more or less comprehensively amend them to improve the state of affairs and/or solve newly arising problems (Coglianese and Kagan, 2007; OECD, 2015b).

According to the literature, the reasons for poor conditions are mostly systemic and partially connected to the operating principles of politics. 
Therefore, when preparing, formulating, implementing, and evaluating PPPP more attention and responsibility should be paid to the management level, which is poorly organized and displays weak skills for preparing long-term development policies and even more so for their regular monitoring and evaluating their effects. Moreover, a review of recent literature shows that long-term monitoring of public policies is of key importance for improvements in the public policy cycle. The purpose of long-term approaches to policy planning is undoubtedly to avoid or to adapt to radical changes in the external environment, which can certainly significantly change the course of a public policy. Capano (2012) places the management of major changes in the context of policy dynamics, with the temporal dimension being an important aspect of PPPP planning. Hence, policymakers should be aware of the importance of long-term PPPP planning. The next section presents our analysis on how various factors influence the public policy process in Slovenia.

\section{Methodological Approach and Data Characteristics}

There are a great number of possible quantitative, qualitative, and mixed methods available and used in public policy analysis and evaluation (see Khandker et al., 2009). It seems that quantitative methods are more frequently used and more reliable when research focuses on the substantive aspects of individual public policy, which was not the case in our research. However, qualitative methods such as focus groups, interviews, and so on can offer much better insight for the in-depth analysis of the factors influencing successful implementation of PPPP. There are also an increasing number of cases in which mixed methods were used (Creswell, 2014; Kustec Lipicer 2009, 112; Burch and Heinrich, 2015). To identify the key driving forces and barriers in successful functioning and design of PPPP, we conducted an empirical analysis using a methodological approach combining structured and semistructured interviews to gather information for our case study. Although interviewing as a research method is perceived as a relatively undemanding methodology to be utilized (Yin, 2009), we should be aware of its advantages and drawbacks when conducting such research (Gill et al., 2008). Namely, this methodological approach is the most suitable for our inquiry about the shaping and functioning of PPPP in Slovenian public administration because it provides and facilitates a more thorough understanding of this complex social and cultural phenomenon (Yin, 2009) in the public policy environment. Interviews are the most widely used tool for collecting information in qualitative research. In our case study, interviews are used as a method to obtain insight from policymakers (Gill et al., 2008; Alshenqeeti, 2014) on how public policies through their policy cycle operate in practice. Hence, it allows us to establish and verify the theoretical presumption on how strategic, institutional, regulatory, methodological, financial, and organizational changes influence the progress and process of PPPP development. At the same time, our preferred methodological strategy in this case study is also 
based on a relatively small sample of possible policymakers with experience in managing PPPP in Slovenia.

In contrast to questionnaires, interviewing as a qualitative approach enables us to collect information based on the detailed insights and knowledge of policymakers about this topic due to the individual setting, which is harder to obtain in a group environment (Kvale, 1996; Cohen et al., 2007; Gill et al., 2008). Moreover, a combination of structured and semi-structured interviews with policymakers makes possible verbal administration of predetermined questions to clarify or further elaborate responses when required and offers flexibility to further pursue a participant's responses or information in a more rigorous manner on specifics in public policy development. Indepth individual interviewing mitigates the potential problems of relevance, validity, inconsistency, or literacy of predesigned interview questions about the holistic view on the functioning and development of PPPP in Slovenia. However, the interview process is time-consuming due to the complex characteristics in designing, conducting, and analyzing it (Alshenqeeti, 2014).

When designing interviews for our research, we also critically examine its structure by conducting a piloting session with a policy expert to improve its content and determine the relevance and validity of questions in elaborating the public policy process. This step helps us anticipate possible problems when applying them to our sample of interviewees in order to gather information. This is crucial when analyzing and establishing relations among key variables and concepts (i.e., strategic, institutional, regulatory, methodological, financial, and organizational) in public policy development in Slovenia. Our interviews also combine closed-ended with open-ended questions, which allows us to obtain quantitative and qualitative information from the interviews. Hence, we used a qualitative approach (i.e., interviews) where most of our questions were quantified using the Likert scale with a five point scale (see Appendix for the interview structure and questions). The integrations of quantitative and qualitative approach can be classified as mixed method design, which is gaining on popularity in public policy analysis. Combining both methods allows us to obtain a better understating of PPPP design in Slovenia. In this regard, the obtained quantitative scores are used as a complementary method to support our qualitative research approach. The information obtained from interviews alleviate the analysis of collected quantitative data. This study shows the most focal quantitative results.

We performed twenty-two interviews with senior officials from February to September 2017, covering various fields of PPPP in Slovenia. The selection process for interviewees and public policies included parallel consideration of the following factors. First, we tried to cover the most relevant public policies in our research that have significant influence on the functioning of Slovenian public administration and beyond. In this regard, our sample structure follows the program classification of PPPP, defined by the Ministry of Finance. This classification shows the budget structure, divided into individual public 
policies, their major programmes and associated projects, which are financed and implemented by the state authorities. The program classification consists of 24 various public policies (see MF, 2017). Another possible classification is according to the functions of government sector (i.e., COFOG), which shows the allocation of public/state funds into 10 government expenditure categories, following the European System of National Accounts (ESA-2010). The advantage of this classification/division is allowing an international comparison across sectors on a macro level. The used classification suits our research purpose, since it provides a better insight in individual policies about the taken measures and activities by policymakers in order to achieve certain policy goals/objectives (Maher, 2011). Table 1 provides the sample structure of covered PPPP in our research.

The second principle taken into account in the selection process was that the senior officials contacted have long-term professional experience in enforcing and implementing changes in these public policies. Following this condition represents a limitation of our research, since it reduces the number of eligible and appropriate interviewees. Our broad sample included 32 appropriate candidates, which was then reduced to 22 interviewees. Hence, our panel includes previous ministers, state deputy secretaries, and heads of institutes or departments at national ministries. By following these principles, the selection strategy made it possible to diminish the political influence in setting candidates in a certain position in public administration and thus allowed us to preserve the objectivity of their answers. However, the selection process accounts some weaknesses of our research. We are aware that the conventional distinction between a political and professional/ administrative relation is ambiguous in the policy process. As thoroughly discussed above, the interaction between politicians as goals-setters and apolitical administration as implementers is interrelated and therefore hard to completely segregate among them. This accounted notion represents a caveat of our research, although our objective was to include professional and apolitical policymakers in our sample.

Table 1. The sample structure of PPPP sectors

\begin{tabular}{|l|l|l|l|}
\hline \multicolumn{4}{|c|}{ PPPP sectors } \\
\hline $\begin{array}{l}\text { Spatial planning policy } \\
\begin{array}{l}\text { Migration and asylum } \\
\text { policy }\end{array}\end{array}$ & Labour and social policy & Science and research & Traffic policy \\
\hline $\begin{array}{l}\text { Migration and asylum } \\
\text { policy }\end{array}$ & $\begin{array}{l}\text { Administrative Law and } \\
\text { Policy }\end{array}$ & $\begin{array}{l}\text { Environmental } \\
\text { protection }\end{array}$ & $\begin{array}{l}\text { Consumer } \\
\text { protection }\end{array}$ \\
\hline Tax policy & Local self-government & Health policy & $\begin{array}{l}\text { Consumer } \\
\text { protection }\end{array}$ \\
\hline Education (primary) & Digital policy & Health policy & Health policy \\
\hline Education (tertiary) & Digital policy & Cultural policy & \\
\hline
\end{tabular}


The sample covers fifteen different public policies (see Table 1). A more detailed look at our sample shows that public policies can be divided into three different levels of distribution. First, we can divide included public policies whether the policy process was evaluated by an external or internal professional in the field of interest. Most public policies were assessed by policymakers working in the public administration or government (13 out of twenty-two policy experts are characterized according to this sample distribution, accounting 59\%). It follows that 9 public policy sectors were evaluated by professionals outside the government. Moreover, some of public policies were appraised by an individual within or outside the government. For example, migration and asylum, health, education, digital, and consumer protection policies can be characterized this way. However, when exploring the policy process in education, we gathered opinions from two internal policymakers and one external policymaker. In contrast, health policy process and functioning was assessed by two external and one internal stakeholders. In addition, our panel of interviewees can be divided into whether they are enforcing changes in public policies at the decision-making or realization level. In this context, the policy cycle process in health policy is characterized by two external experts, whereby one of them creates programs and projects at the decision-making level, and the other looks at the realization of those designed programs and projects in practice. Another example is related to the assessment of budget and tax policy. Our sample includes an expert dealing with the design of budget consolidation policy, which is part of the decision-making function in the policy process. This process is implicitly and mutually related with the realization process of measures in the field taxation. Nevertheless, the majority of interviewees assess the policy process from a decision-making angle ( $91 \%$ or twenty out of twenty-two interviews). Another classification in our sample is the distinction between vertical or sectoral and horizontal programs and projects within certain public policies. Most of our interviews cover the vertical coordination of programs and projects in policymaking ( $77 \%$ or seventeen out of twenty-two interviews are more in line with the vertical coordination of enforced changes in the decision-making process). Table 2 summarizes a detailed distribution of our sample according to listed categories above.

Table 2. The sample categorization of PPPP

\begin{tabular}{|l|l|l|l|l|l|}
\hline \multicolumn{2}{|c|}{ Governance level } & \multicolumn{2}{c|}{ Policy scope } & \multicolumn{2}{c|}{ Position of interviewees } \\
\hline $\begin{array}{l}\text { Decision- } \\
\text { makers }\end{array}$ & Implementers & Sectoral & Horizontal & Internal & External \\
\hline $20(91 \%)$ & $2(9 \%)$ & $17(77 \%)$ & $5(23 \%)$ & $13(59 \%)$ & $9(41 \%)$ \\
\hline
\end{tabular}

Source: own calculations. 
Our interview is divided into seven sections of questions. In Appendix we have disclose the whole interview structure and questions. The first section refers to general information and explores which instruments for designing public policies are used in Slovenian administration. Designing PPPP needs to be supported by various instruments in order to utilize certain goals and prospects in their development. Our inquiry regarding the use of the main instruments for managing the entire policy cycle in public policies reveals that most policymakers in Slovenia act in accordance with strategies, resolutions, or action plans in their field (eighteen public policies rely on such documents). In general, this result is in line with the conceptual framework that those designing the policy process follow strategies. Nevertheless, these documents must be consistent with national and supranational rules. Thus, as expected, the next most commonly used instruments in shaping public policies are national (eleven interviewees acknowledged their contribution) and/or EU regulations (nine public policymakers considered them a vital instrument in their functioning), which obviously must be acknowledged by policymakers when designing changes in PPPP. This is related to the fact that Slovenia is a member the EU, meaning that legislation should be harmonized and applied in all member states.

Nevertheless, some public policies are under national restrictions and autonomous, and so the policy can be shaped individually according to national priorities and views on its development. For example, to some extent, shaping of cultural programs and projects can be viewed as an independent and autonomous public policy at the national level. Due to the impact of international and recognized institutions on governance, policymakers recognize and comply with their guidelines on how changes should be applied in order to improve the policy process and strengthen its development. Thus, international organization guidance is the fourth most frequently adopted policy instrument. Only three times did policymakers highlight (co)financing as vital instrument in designing policy decisions. This implies that most public policies covered in our research appear to be financially independent in the policymaking process. On the one hand, this is related to the selection of public polices in our sample. On the other hand, this is also due to the fact that funding from various sources (e.g., the Cohesion Fund) has been reduced, which is partly associated with the current financial crisis. In addition, Slovenia established certain public policies with the help of funding from the EU and now their development is mostly financed by national funds. Figure 1 shows the frequencies of answers regarding the use of the main instruments in designing and monitoring the entire policy cycle process. 
Figure 1. Use of main instruments in shaping PPPP

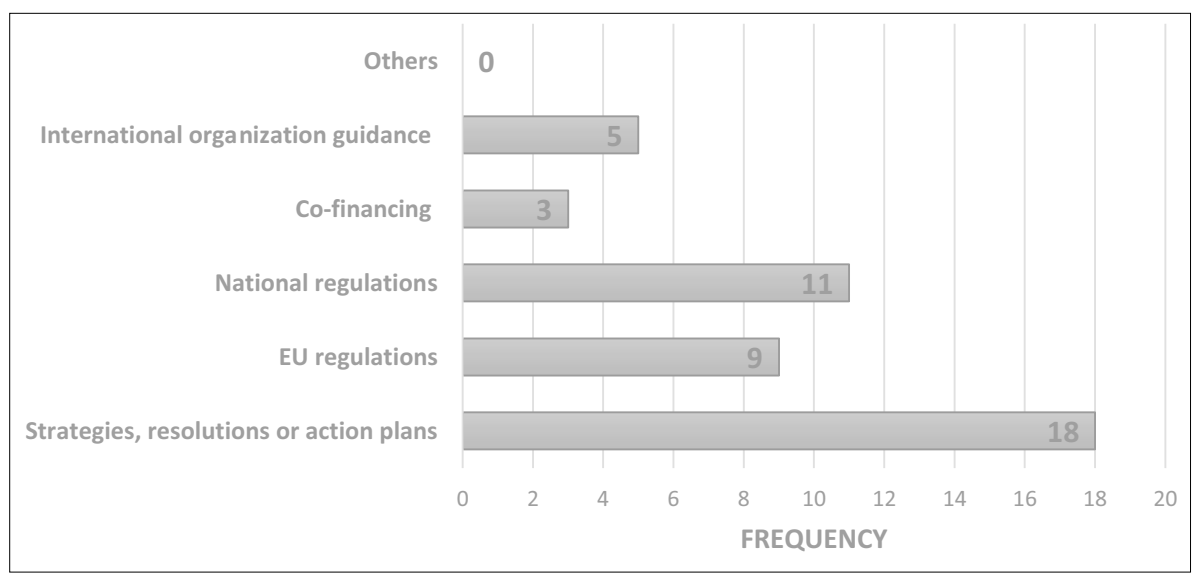

Source: own calculations.

\section{Empirical Results of PPPP Design in Slovenia}

The focal point of our interviews was to determine which factors have a significant impact on the decision-making process in shaping PPPP in Slovenian public administration. In this regard, we identified six interrelated components: strategic, institutional, regulation, methodological, financial, and organizational. Hence, the aim was to analyze and explore how changes in those critical factors facilitate or inhibit the policy process at all of its stages (i.e., agenda-setting, ex-ante evaluation, policy formulation, decisionmaking, policy implementation, and ex-post evaluation). Moreover, we want to explore whether the policy design process in Slovenia follows a systematic and coherent approach in PPPP development.

The evidence shows that most policymakers agree or strongly agree with the notion that changes in these categories have a substantial impact on the development of the policy process in various public policies. Looking at the top box scores, up to $70 \%$ of respondents feel that strategic determinants are pivotal in the policy process, which is followed by organizational (37\%), regulation-related (35\%), and finally financial and institutional factors (both 29\%). When looking at the top two box scores, the importance of predetermined determinants rises, although their priority sequence slightly changes. Table 3 shows the top and top two-box scores for all categories. We can confirm a high level of relevance and the validity of our depicted determinants in shaping public policies in Slovenia because roughly $70 \%$ or more policymakers confirmed this notion. Consequently, the results obtained from our empirical analysis may be useful for practitioners in understanding the complexity of public policy development. In the next stage of our analysis, we asked policymakers to discuss each individual determinant and how those have an impact on establishing better development of public policies and their derived programs and projects. 
Table 3. Top box and two-box scores for the relevance of various factors

\begin{tabular}{|l|l|l|l|l|}
\hline & $\begin{array}{c}\text { Top box } \\
\text { score }\end{array}$ & Ranking & $\begin{array}{c}\text { Top two-box } \\
\text { score }\end{array}$ & Ranking \\
\hline Strategic & 0.70 & 1 & 0.80 & 2 \\
\hline Institutional & 0.29 & 4 & 0.67 & 6 \\
\hline Regulation & 0.35 & 3 & 0.90 & 1 \\
\hline Methodological & 0.25 & 5 & 0.70 & 5 \\
\hline Financial & 0.29 & 4 & 0.71 & 4 \\
\hline Organizational & 0.37 & 2 & 0.79 & 3 \\
\hline
\end{tabular}

Source: own calculations.

First, let us take a closer look at how the strategic factor affects the development of public policies in Slovenia. Our premise in this part derives from a theoretical understanding that effective and comprehensive utilization of PPPP must rely on a systematic framework with integrated mandatory targets in the long term. This element should be integrated in created strategic documents by defining a vision for the effective and efficient development of each public policy process at the national and supranational levels. Our research indicates a roughly balanced distribution of public policies in the sample regarding their dependence on a particular institutional framework in shaping its policy process. In particular, the development of nine public policies (39\%) are informally shaped in accordance with EU regulations. This implies that the policy process follows the EU regulation framework requirements only to a certain extent. Most public policies can be characterized as such. This type of public policy is followed by those with no obligations from other supranational institutions in designing and implementing policy measures (i.e., the development of eight public policies, or $35 \%$, in our sample is under national restrictions or initiatives). Moreover, $26 \%$ or six public policies in our sample have to comply with EU regulation requirements and guidance. This means that they formally operate under the supervision of the European Commission. Our analysis also shows that fourteen out of twenty-two (top two-box score accounts, or 67\%) policymakers agree with the notion that the adoption of various strategic documents has a significant impact on the efficiency and effectiveness of the PPPP policy process. Another important aspect is the operationalization and implementation of public policies after enacting different types of strategic documents by government bodies. In this regard, policymakers ranked possible factors that may mitigate the operationalization of public policies. When ranking them according to assigned percentage responses by participants, the following factors contribute to this policy aspect: 1) government support, 2) clearly defined strategic objectives, 3) capacity of the government to engage in the policy process, and 4) organizational capacities of the public sector. Surprisingly, most policymakers (seven) ranked the engagement of public support as the least important 
factor in the operationalization process. However, most studies show that a positive public opinion can mitigate the implementation of measures in PPPP (Burstein 2003). Moreover, $42 \%$ of respondents share the opinion that the current government mostly ignores strategic documents that were adopted and compiled by the previous government. This implies that Slovenian public administration lacks policy capacity and long-term prospects when it comes to the development of PPPP in the future. Table 4 summarizes the results obtained.

Table 4. Summary of results on the importance of the strategic factor

\begin{tabular}{|c|c|c|c|}
\hline & \\
\hline & Yes & Partly & No \\
\hline \multirow[t]{2}{*}{$\begin{array}{l}\text { The public policy-making process is formulated and } \\
\text { designed in accordance with EU legislation. }\end{array}$} & 0.26 & 0.39 & 0.35 \\
\hline & \multicolumn{3}{|c|}{ Top two-box score } \\
\hline $\begin{array}{l}\text { The adoption of strategic documents has a significant } \\
\text { impact on policy processes. }\end{array}$ & \multicolumn{3}{|c|}{0.67} \\
\hline \multicolumn{2}{|c|}{$\begin{array}{l}\text { The operationalization process of public policies depends on the } \\
\text { following factors: }\end{array}$} & \multicolumn{2}{|c|}{ Ranking } \\
\hline \multicolumn{2}{|l|}{ Government support } & \multicolumn{2}{|c|}{1} \\
\hline \multicolumn{2}{|l|}{ Policy capacity of the public sector } & \multicolumn{2}{|c|}{3} \\
\hline \multicolumn{2}{|l|}{ Clearly defined strategic objectives } & \multicolumn{2}{|c|}{2} \\
\hline \multicolumn{2}{|l|}{ Organizational capacity } & \multicolumn{2}{|c|}{4} \\
\hline \multicolumn{2}{|l|}{ Sufficient financial resources } & \multicolumn{2}{|c|}{5} \\
\hline \multicolumn{2}{|c|}{$\begin{array}{l}\text { The policy process and responsibilities of stakeholders are firmly } \\
\text { defined }\end{array}$} & \multicolumn{2}{|c|}{6} \\
\hline \multicolumn{2}{|l|}{ Public support } & \multicolumn{2}{|c|}{7} \\
\hline & \multicolumn{3}{|c|}{ Top two-box score } \\
\hline $\begin{array}{l}\text { The current government mostly ignores strategic } \\
\text { documents compiled by the previous one. }\end{array}$ & \multicolumn{3}{|c|}{0.42} \\
\hline
\end{tabular}

Source: own calculations.

Second, the impact of institutional factors on the public policy process is considered. We wanted to shed light on the institutional structure of public administration regarding enabling and facilitating the functioning of PPPP. In particular, more than half of policymakers (top two-box score 57\%) agree that the current institutional framework allows monitoring in all policy cycle stages (i.e., agenda-setting, ex-ante evaluation, policy formulation, decision-making, policy implementation, and ex-post evaluation). However, there is a non-trivial share of respondents ( $43 \%$ of them are undecided or disagree with this notion) that argue that certain stages in the policy cycle are neglected although the institutional framework supports the functioning of the policy process in all stages. This is the case in migration, education at the tertiary level, and cultural and labor policy. Most of the time this is 
related to a shortage of and incompetence in organizational capacity and impaired horizontal linkages with other departments. To a certain degree, this is reflected in the response if the institutional framework makes possible a horizontal approach in functioning of PPPP. Although a non-trivial degree of policymakers agree with this notion (the top two-box score is $38 \%$ ), we found that $38 \%$ of respondents are undecided or even disagree (24\% of them) with it. A similar explanation can be concluded when considering whether the institutional framework makes it possible to establish accountability of stakeholders in particular stages of the policy cycle process. Namely, most of respondents are undecided (44\%) or even disagree with it (the bottom twobox score is $19 \%$ ). However, a top two-box score of $38 \%$ shows that a relevant share of policymakers can determine the responsibility of stakeholders when monitoring the policy process. In addition, our analysis shows that a change of government and subsequent reorganization of ministries has a substantial impact on PPPP functioning. This was confirmed by $70 \%$ of respondents in our research. This can be worrying for the sustained and constant development of PPPP. Table 5 presents selected results for this part.

Table 5. Summary of the effects of the institutional factor

\begin{tabular}{|l|c|c|c|}
\hline The institutional framework: & $\begin{array}{c}\text { Bottom two- } \\
\text { box score }\end{array}$ & Undecided & $\begin{array}{c}\text { Top two- } \\
\text { box score }\end{array}$ \\
\hline $\begin{array}{l}\text { a) Allows monitoring in all policy cycle } \\
\text { stages }\end{array}$ & 0.19 & 0.24 & 0.57 \\
\hline $\begin{array}{l}\text { b) Enables a horizontal/sectoral } \\
\text { approach }\end{array}$ & 0.24 & 0.38 & 0.38 \\
\hline $\begin{array}{l}\text { c) Makes it possible to determine } \\
\text { stakeholder accountability }\end{array}$ & 0.17 & 0.44 & 0.39 \\
\hline $\begin{array}{l}\text { Change of government and } \\
\text { reorganization of ministries has a } \\
\text { substantial impact on PPPP functioning. }\end{array}$ & \multicolumn{3}{|c|}{ Top two-box score } \\
\cline { 2 - 4 } & \multicolumn{2}{|c|}{0.70} \\
\hline
\end{tabular}

Source: own calculations.

In the third part, our research focuses on the regulatory framework and how exiting regulatory changes influence the development and functioning of PPPP. As shown in Table 3, this is the most important factor considering the top two-box ranking. The evidence of its relevance is related to the fact that the majority of policymakers find a significant causal relationship between realization of PPPP and adjustment of sectoral legislation. This is confirmed by $67 \%$ of respondents. When enacting sectoral legislation, around $62 \%$ of policymakersagreethatmost other essentialfactorsor changesare defined and considered in the light of effective and efficient realization of PPPP. However, a comparison of top and bottom two-box scores shows disagreement with the statement on whether policymakers fail to provide adequate resources (i.e., financial, organizational, etc.) when adopting modifications in the sectoral legislation for PPPP. More than half of respondents (52\%) disagree 
with this notion, whereas $38 \%$ of respondents agree with it. This shows a distinctive inconsistency when policymakers try to implement and realize the changes adopted and priorities of the sectoral legislation in practice. Clearly, the majority of policymakers (90\%) strongly support the authorization of expost regulatory analysis, which would facilitate more systematic functioning and development of PPPP. However, policymakers notice that only changes in regulation or even implementation of new regulations will not entirely solve the problems in development of PPPP. They main problem is the lack of policy capacity in Slovenian public administration. Table 6 summarizes these results.

Table 6. Summary of results regarding the PPPP regulation framework

\begin{tabular}{|c|c|c|}
\hline \multirow{2}{*}{$\begin{array}{l}\text { There is a significant causal relationship between realization } \\
\text { of PPPP and adjustment of sectoral legislation. }\end{array}$} & \multicolumn{2}{|c|}{ Top two-box score } \\
\hline & \multicolumn{2}{|c|}{0.67} \\
\hline \multirow{2}{*}{$\begin{array}{l}\text { Policymakers consider the most essential factor when } \\
\text { enacting sectoral legislation. }\end{array}$} & \multicolumn{2}{|c|}{ Top two-box score } \\
\hline & \multicolumn{2}{|c|}{0.62} \\
\hline \multirow[t]{2}{*}{$\begin{array}{l}\text { Policymakers provide adequate resources (i.e., financial, } \\
\text { organizational, etc.) when adopting modifications in sectoral } \\
\text { legislation. }\end{array}$} & $\begin{array}{l}\text { Bottom } \\
\text { two-box } \\
\text { score }\end{array}$ & $\begin{array}{l}\text { Top } \\
\text { two-box } \\
\text { score }\end{array}$ \\
\hline & 0.52 & 0.38 \\
\hline \multirow{2}{*}{$\begin{array}{l}\text { Ex-post regulatory analysis would provide more systematic } \\
\text { functioning and development of PPPP. }\end{array}$} & \multicolumn{2}{|c|}{ Top two-box score } \\
\hline & \multicolumn{2}{|c|}{0.67} \\
\hline
\end{tabular}

Source: own calculations.

The fourth part concerns the weight of the methodological/procedural approach on different stages in the policy cycle process of PPPP. This section focuses on whether policymakers apply suitable methodological approaches and measurements to achieve the comprehensive and systematic development of PPPP. We explored which stages of the policy cycle policymakers focus on and which are neglected. This shows a possible gap between the theoretical understanding of using a systematic and comprehensive approach and realization in practice. We ranked seven policy cycle stages (see Table 7) according to the top two-box scores. Our analysis shows that policymakers are diligent in the following stages: issue identification (75\%), decision-making (67\%), consultation (57\%), and policy implementation (55\%). In particular, more than half of respondents think that those policy cycle stages operate according to theoretical premises. Nevertheless, the stage of consultation has a relatively low percentage of affirmation (52\%) because some policymakers think that although consultation takes place it is just a formality without any meaningful outcome. Policymakers indicated that stages of policy monitoring and evaluation, policy instrument development for alternative solutions, and preparation of corrective measures are not fully utilized to better exploit the development of PPPP. According to the respondents, corrective measures are mostly not considered during the current adopted strategy. Furthermore, 
when it comes to deviations in the policy process, our research indicates that the most common applied measure is modifying PPPP (60\% confirmation of respondents). This measure is followed by alternation of regulation of public policy (50\%), whereas augmenting or changing strategy documents is the least probable measure to be applied under such circumstances. In particular, 65\% of respondents disagree with the stance that changes in strategic documents would be applied when an irregularity or failure in achieving certain public policy goals is noticed. As mentioned, the monitoring and evaluation stage should be improved, especially by applying ex-ante or ex-post analysis to the proposed or enacted measures. Our analysis shows that the financial factor is most viable in both approaches. This implies that policymakers are more concerned about financial consequences when preparing and implementing measures for the development of PPPP. Subsequently, this constraint can have a detrimental effect on its future performance and progress. We asked policymakers which stages of the policy cycle process show a lack of indicators to evaluate PPPP progress and performance. Hence, our analysis indicates that the highest shortage of indicators is in the stage of policy evaluation ( $56 \%$ confirm the scarcity of indicators in this stage), followed by the stages of planning (45\%), decision-making (40\%), and implementation (40\%). This means that roughly half of policymakers notice a deficient coverage of indicators in these stages. Nevertheless, most respondents argue that the main issue is the use and linkage of indicators in analyzing the progress of PPPP. Thus, content-related indicators are missing, which could allow policymakers to quantify the realization of predicted and achieved goals of PPPP in practice. Table 7 shows our analysis of the impact of methodological process on PPPP development.

Table 7. Summary of the impact of the methodological process

\begin{tabular}{|c|c|c|}
\hline \multicolumn{2}{|l|}{ Policymakers focus on the following policy cycle stages: } & Ranking \\
\hline \multicolumn{2}{|l|}{ a) Issue identification } & 1 \\
\hline \multicolumn{2}{|l|}{ b) Рreparation of alternative solutions } & 6 \\
\hline \multicolumn{2}{|l|}{ c) Consultation } & 3 \\
\hline \multicolumn{2}{|l|}{ d) Decision-making } & 2 \\
\hline \multicolumn{2}{|l|}{ e) Policy implementation } & 4 \\
\hline \multicolumn{2}{|l|}{ f) Monitoring and evaluation } & 5 \\
\hline \multicolumn{2}{|l|}{ g) Corrective measures } & 7 \\
\hline $\begin{array}{l}\text { The most commonly applied measure for deviations in } \\
\text { the policy process by policymakers are: }\end{array}$ & $\begin{array}{c}\text { Bottom two- } \\
\text { box score }\end{array}$ & $\begin{array}{l}\text { Top two- } \\
\text { box score }\end{array}$ \\
\hline a) Augmenting and changing strategic documents & 0.65 & 0.00 \\
\hline b) Changing the regulation of public policy & 0.20 & 0.50 \\
\hline c) Modifying PPPP & 0.15 & 0.60 \\
\hline
\end{tabular}




\begin{tabular}{|l|c|}
\hline $\begin{array}{l}\text { There is a lack of indicators in the following policy cycle } \\
\text { stages: }\end{array}$ & Top two-box score \\
\hline a) Planning & 0.45 \\
\hline b) Decision-making & 0.40 \\
\hline c) Policy evaluation & 0.56 \\
\hline d) Implementation & 0.40 \\
\hline
\end{tabular}

Source: own calculations.

In the fifth part of our research, we account for the influence of the financial factor on the functioning of PPPP. In particular, we were interested in whether the structure and stability of policy financing is independent and whether financing is transparent and consistent with binding fiscal constraints (i.e., following performance-based budgeting). A sustainable financial framework allows us to achieve the efficient and effective implementation of various PPPP. In theory this is known as public financial management (PFM), which in the traditional sense deals with how governments manage the budget in its established stages: formulation, approval, and execution (Cangiano et al. 2013). Our analysis shows that the main factors influencing the structure and stability of financial resources are politics and other external factors, such as the financial crisis. This is corroborated by $70 \%$ of public policy respondents, considering the top two-box ranks. In contrast, public influence or lobbying has a minor effect on financial flows and structure. As already confirmed above, we again notice a major political influence on the development of PPPP through disruption of financial stability. This is counter to the theoretical background, where political influence ought to be mitigated. Namely, PPPP should be promoted in order to achieve greater wellbeing of society. The impact of the financial crisis is difficult to avoid; however, progress in the most important public policies for the entire society should be preserved. Furthermore, the majority of policymakers agree that the defined strategic goals are covered by explicit target values in the budget. This is in alignment with public financial management systems (e.g., performance-based budgeting) in order to strengthen countries' capacity to better manage their public finances (i.e. preserving fiscal sustainability and soundness of public finance in the long term ${ }^{4}$ ) and effectively provide high-quality public services for a wider range of users (Cangiano, et al. 2013; Lavrov et al. 2006). Table 8 represents the results of the influence of the financial/economic factor on PPPP design.

4 To inspect in detail the implications of fiscal prudence and profligacy, see Mencinger and Aristovnik (2013), Mencinger et al. (2014; 2015). 
Table 8. Summary of the influence of the financial factor

\begin{tabular}{|l|c|}
\hline $\begin{array}{l}\text { The main factors influencing the structure and stability of } \\
\text { financial resources }\end{array}$ & Top two-box score \\
\hline a) Politics & 0.70 \\
\hline b) Lobbying & 0.20 \\
\hline c) External factors & 0.68 \\
\hline $\begin{array}{l}\text { Strategic goals are covered with explicit target values in the } \\
\text { budget. }\end{array}$ & Top two-box score \\
\cline { 2 - 2 } & 0.63 \\
\hline
\end{tabular}

Source: own calculations.

The last part of our research deals with the relationship between the organizational factor and development of PPPP. In this regard, we are interested in whether public policies rely on individual organizational policy units, which allows them comprehensive surveillance of the entire policy cycle process when formatting, evaluating, and monitoring PPPP. On the one hand, our analysis indicates that the established organizational policy unit most commonly enables policymakers to format (71\%), monitor (79\%), and ex-post evaluate the results (57\%) of PPPP. In all cases, at least half of the respondents support this statement. On the other hand, objective assessment of alternative policies is less frequently used by policymakers. Only $42 \%$ think that this objective of organizational unit is supported and utilized by them. There is a strong positive stance on whether the organizational unit is positioned at a proper administration level in the bureaucratic hierarchy. According to the top two-box score, $75 \%$ of respondents consider positioning of the organizational policy unit to be appropriate in the hierarchical structure of public administration. If this organizational unit does not exist, those tasks аге assigned and shared among the ministry's departments (58\% of the time) or transferred to an ad-hoc formatted work group (42\% of the time). In our research, we explored aspects that may have detrimental effects on the development and progress of PPPP. The results show that weak organizational capacity, an unsystematic process of determining goals, and non-existence of a common public policy framework are the most pronounced factors that can negatively influence the policy cycle process of PPPP in Slovenian administration ${ }^{5}$. In addition, policymakers are undecided when asked about the absence of the previous discussed organizational unit and how this would affect the functioning of PPPP. The least problematic factors, although very relevant, are a vague allotment of responsibilities among peers, frequent personnel changes, and inappropriate organizational structure. Table 9 presents the results obtained in this part.

5 The order follows the ranking according to the top two-box scores. The same analogy is used when listing other factors. 
Table 9. Summary of the impact of the organizational factor

\begin{tabular}{|c|c|c|}
\hline $\begin{array}{l}\text { The established organizational policy unit most } \\
\text { commonly enables policymakers to: }\end{array}$ & \multicolumn{2}{|c|}{ Top two-box score } \\
\hline a) Format & \multicolumn{2}{|c|}{0.71} \\
\hline b) Objectively assess alternative policies & \multicolumn{2}{|c|}{0.42} \\
\hline c) Monitor & \multicolumn{2}{|c|}{0.79} \\
\hline d) Ex-post evaluate results & \multicolumn{2}{|c|}{0.57} \\
\hline \multirow{2}{*}{$\begin{array}{l}\text { The organizational unit is positioned at a proper } \\
\text { administration level. }\end{array}$} & $\begin{array}{l}\text { Bottom two- } \\
\text { box score }\end{array}$ & $\begin{array}{l}\text { Top two- } \\
\text { box score }\end{array}$ \\
\hline & 0.08 & 0.75 \\
\hline \multicolumn{3}{|c|}{ When an organizational unit does not exist, the policy process tasks are: } \\
\hline $\begin{array}{l}\text { a) Assigned and shared among the ministry's } \\
\text { departments ( } 58 \% \text { of the time) or }\end{array}$ & \multicolumn{2}{|c|}{0.58} \\
\hline $\begin{array}{l}\text { b) Transferred to an ad-hoc formatted work group } \\
\text { ( } 42 \% \text { of the time) }\end{array}$ & \multicolumn{2}{|c|}{0.42} \\
\hline $\begin{array}{l}\text { Factors that may have detrimental effects on the } \\
\text { development and progress of PPPP: }\end{array}$ & \multicolumn{2}{|c|}{ Top two-box score } \\
\hline a) Unsystematic process of determining goals & \multicolumn{2}{|c|}{0.60} \\
\hline $\begin{array}{l}\text { b) Non-existence of a common public policy } \\
\text { framework }\end{array}$ & \multicolumn{2}{|c|}{0.60} \\
\hline c) Vague allotment of responsibilities & \multicolumn{2}{|c|}{0.52} \\
\hline d) Inappropriate organizational structure & \multicolumn{2}{|c|}{0.33} \\
\hline e) Weak organizational capacity & \multicolumn{2}{|c|}{0.76} \\
\hline f) Frequent organizational changes & \multicolumn{2}{|c|}{0.48} \\
\hline g) Absence of an organizational unit & \multicolumn{2}{|c|}{0.50} \\
\hline
\end{tabular}

Source: own calculations.

\section{Discussion and Recommendations}

The main aim of our research was to shed light on the state of the art in Slovenian PPPP design and implementation, to identify and explore the key driving forces for successful PPPP design. Our assumptions concerning the lack of a holistic approach, strategic planning, long-term sustainable orientations, and professionalism in all stages of PPPP design have largely been confirmed (as defined, among others, by Jann and Wegrich, 2007; Bevir, 2011; Savard and Banville, 2012; von Raggamby and Rubik, 2012).

Our interviewees highlighted several positive approaches and experiences in Slovenian public administration. On the other hand, many seem to mostly exist in name only or аге incoherent. For instance, the strategic dimension of PPPP design is strongly emphasized by all experts, but regulation ranks as a primary policy tool in the majority of administrative fields (see the discussion of 
results in the previous section). Or: the institutional framework is mostly seen as satisfactory, yet $43 \%$ of respondents argue that certain stages in the policy cycle are neglected. The lack of an integral approach is further illustrated by significant differences in the importance of the six sets of factors according to our survey because the range varies between $29 \%$ (e.9., institutional and financial factors) and $70 \%$, whereas we expected all of them to be inevitably connected and to see rather minor differences.

Nevertheless, the main gaps identified address a lack of all stages in the policy cycle (consequently, a disconnected cycle) and an absent policy unit as a core center for overall PPPP design and individual policies alike. Even though this is the case, the majority of interviewees evaluate the institutional dimension as almost unimportant (ranking sixth out of six sets of factors; see Table 3). One crucial research finding is that Slovenian administrators underestimate the role of different inevitably connected factors and stages in PPPP design.

In addition, we have established that Slovenia expresses some overall posttransitional eastern European characteristics (see Kovač and Bileišis, 2017, OECD, 2015a), such as formalism with overregulation regrading PPPP adoption and implementation, an overly strong role of daily politics as opposed to professional decision-making, and public consultation and regulatory impact assessments conducted in a rather pro forma manner (if at all). For example, almost $40 \%$ of interviewees see EU regulations after over a decade of Slovenia's EU membership (since 2004) as a key guideline to follow when PPPP design is in question. If the national regulations were added, the share increases up to $62 \%$ regarding sectoral policies. It is obvious that normativism is often an approach to diminish the accountability of otherwise responsible decision makers because several experts reported that policy becomes valid and financed only when grounded by law, is de facto designed by ministers and their external pressure groups, and is de jure adopted by the parliament. Moreover, politics and polity have grown beyond professional administrators. It is indicative that almost half of respondents (42\%) view even strategic documents (usually addressing the mid- or long-term period) prepared by former governments as made obsolete by the current one by simply ignoring these policy papers (e.g., in science, internal affairs, and social welfare). If one intends to introduce a policy, it cannot be done without government support (see Table 4). This is self-evident to a certain extent, but the role of daily politics will seem to be overly influential. A negative effect is seen when the interviewees report that a change of government most significantly affects PPPP functioning (as in 70\%; see Table 5) and politics is the main factor in stabile financial resources (by $70 \%$ of respondents' assessment, see Table 8 ).

Regarding regulatory impact analysis, public consultation, and reducing red tape, Slovenia has adopted several policy papers and regulations, such as the parliamentary Resolution on Legislative Regulation (2009), or constantly improving governmental rules of procedure and supplementary materials. However, the level of compliance is rather low even regarding prescribed 
procedures, as reported by non-governmental organizations, the court of audit, and academic research (for more, see Kustec Lipicer, 2009; Kovač, 2017), and our findings regarding methodological factors of PPPP design (see Table 3 with a rank of five out of six). Public support for individual PPPP is regarded as almost not relevant at all (see Table 4), although contemporary sound governance requires shared decision-making in public affairs (for more, see Bevir 2011; cf. OECD 2015b). Regarding ex-post evaluation, 90\% of interviewees support this step as an inevitable one, yet monitoring is ranked only fifth and corrective measures as even the last out of seven policy cycle stages in real practice (see Table 7). When asked why officials do not conduct these steps, the answer is usually that daily politics would not allow it, most often because certain decisions need to be adopted as soon as possible with immediate effects in public. In this context, it is not surprising that alternative solutions to a certain issue are almostnever designed and discussed. Alternative forms of solutions are assessed as only the sixth most frequent step in the PPPP cycle out of seven, only before the introduction of correction measures. Such phenomena are contrary to the theoretical understanding of the longterm cyclic review of PPPP and good public governance (cf. Capano 2012). In order to overcome complex social problems, an integral and interdisciplinary approach to PPPP is therefore necessary (Raadschelders, 2011).

As the most worrying point, we see a difference between the shares of respondents that evaluate certain policy cycle stages to be carried out in practice (see Table 7). Namely, although issue identification is present as the most frequent, with $75 \%$ of answers, the implementation stage is only the fourth (out of seven), with only 55\%. Furthermore, when the entire cycle is carried out, only the financial impact and burdens are given attention whereas other consequences are overlooked (such as social, environmental, or administrative burdens, cf. Radaelli and De Francesco, 2007; Kovač, 2017). Several respondents have explicitly reported that, in addition to political pressure, it is particularly a lack of indicators to evaluate PPPP progress that leads to such a result. We can conclude that approximately $20 \%$ of all problems detected are not resolved despite a clear social need being established. In other words: when the discrepancy between issue identification and corrective measures is one (the most frequent) to seven (the rarest), apparently the capacity is not high and overall governance is rather poor.

Often the problems above arise due to an improperly positioned existing unit (e.g., only as a ministerial department, not hierarchically high enough), but in $42 \%$ of cases there is no policy unit established at all and policies are designed through ad hoc groups only (see Table 9). According to the contemporary practices we have identified, in the majority of bodies that are responsible for their implementation, monitoring, and evaluation (e.g., from environmental protection, traffic, and digital infrastructures to industrial politics) the policymaking business functioning within relevant government bodies (ministries, directorates, agencies, etc.) is poorly developed or does not 
even exist in the form of an independent specialized analysis organizational unit. Therefore, almost every ministry faces difficulties, on the one hand in the preparation of strategies, development programs and projects, objective evaluation of alternatives, and preparation for verified decision-making, and on the other hand with regular follow-up and evaluation of implementation results. These development activities that require a systematic and long-term directed approach are mostly handled by expert teams created ad hoc that are often unfamiliar with the actual circumstances. Sector-specific public policy programs are prepared by order of the currently ruling coalition, but no one is responsible for their (non)execution due to the constantly changing government and initiators of such ad hoc programs and projects, and no one ensures the continuity of long-term directed planning and implementation of PPPP.

Analysis of thishas beenconducted in theSlovenianframeworkfor the firsttime. Hence, we believe we can put forward several data-based recommendations for future PPPP cycle improvements. The key ones are the following. First, there is a need to define responsibilities and accountability between political appointees and the most senior professional officials in public administration more transparently. Thus, clearer differentiation of political influence and administrative governance is possible, with a strengthened level of the latter and more limited daily politics.

Second, a focus on implementation of already existing metaregulation on PPPP design is required. Respective metaregulation has already been adopted in Slovenia, prescribing among other things inter-ministerial coordination, regulatory impact analysis, and public consultation proportional to the scope of individual PPPP, but an overview mechanism such as a gatekeeper, overall accountability, and capacities in ministries are missing. Third, metaregulation of PPPP design or key sectoral laws should be improved. We see possibilities in introducing obligatory ex-post analysis of any regulation and rules adopted in, say, three years, and comparing legislative goals to law implementation.

Fourth, it is abundantly clear that an overall PPPP design model should be developed, with indicators measuring potential inconsistencies within PPPP cycle stages-and, if they occur, to then fill the gap promptly. Such a model and metaregulation of the PPPP cycle also comparatively proves to be an efficient tool to limit overly political decisions and increase professionalism (cf. Radaelli and De Francesco, 2007). Fifth, we recommend forming step-by-step special policy units at the center of government for horizontal policies and directly under the ministers for sectoral policies. In addition, the support of these units is to be guided centrally with methodological and IT tools to carry out individual policy processes in a unified way yet with the ability to adjust the tools to the specifics of different polices, projects, or administrative fields.

Our research confirms that PPPP design is effective as far as it is carried throughout the entire cycle coherently. When certain steps are missing or 
underestimated, the effects are not optimal or even counterproductive. When developing a holistic model of PPPP, all of these should be part of the overall puzzle as theoretical grounded by different governance doctrines (see Stewart and Ayres, 2001; Ostrom, 2011; Bevir, 2011). Moreover, various dimensions of PPPP design need to be taken into account, which can be grouped as related to strategic, institutional, regulative, methodological, financial, organizational, and information systems. Such a model needs to be systemic but still allow flexible application, which is possible when individual indicators are designed.

\section{Conclusion}

The PPPP cycle is an integral process in its character, following basic theoretical definitions. As such, all of its stages and their interdependence should be taken into account primarily in policy-making at the strategic level, or in socalled institutional public governance. However, individual countries face different difficulties when addressing increasingly complex contemporary society with its thorny issues to resolve, which is challenging in particular for (post)transitional and smaller societies. Particularly due to the complexity of the demanding environment, PPPP design needs to be seen as a systematic and coherent process in order to achieve good public governance principles and goals. As shown by the Slovenian example, a contrary approach leads to counterproductive effects, although many PPPP holders invest significant effort into individual stages.

Based on empirical research results, special attention in the future is required regarding the professionalism of PPPP design, among other things to mitigate what is currently practice that depends too much on the government of the day. Furthermore, ex-post evaluation should be an inevitable step in reviewing any policy or project after its adoption, regardless of its scope for specific administrative sectors or even horizontal policies. Such policies, including deregulation, e-government, administrative processes, local selfgovernment, or civil service development, deserve a special position because their spillover affects public administration as a whole and, consequently, represents a stimulating or hindering factor in overall social progress. However, the limitations of our research are following. Although our study accounts various heterogeneous public policies, the generalization for the whole public policy process in Slovenia is limited. This is related with the use of a simple methodological approach to presents the relevance and validity of our depicted factors in shaping public policies. Nevertheless, the results obtained from our empirical analysis may be useful not only for researchers who are working on similar questions but also for practitioners in understanding the complexity of public policy development. Also, our analysis raises some additional research question, which should be addressed in future research. For example, whether our answers across PPPP sectors are applicable when 
only looking at a certain public policy sector in depth. The distinction between internal and external policy makers presents an interesting research path, which can additionally elucidate the understanding of public policy design in Slovenia. Hence, further research is still warranted.

Jernej Mencinger is a part-time researcher at the Faculty of Administration, University of Ljubljana. His main research interest is in applied economics and macroeconomics, with particular focus on fiscal policy and public economics.

Polonca Kovač is an Associate Professor of Administrative Law at the Faculty of Administration, University of Ljubljana. She is as a steering committee member of the NISPAcee and a co-director of the Law and Administration panel of the EGPA. She has over 20 years of working experiences, also internationally as an OECD, WB, SIGMA and ReSPA expert. She is or has been a member of several (inter) national research projects and (co-)author of numerous scientific papers, mainly on Europeanisation of administration and modernisation of administrative procedures, as well as monographs, e.g. The Laws of Transparency in Action (2018), European Administrative Space (2017), Public Administration Reforms in Eastern EU (2017), Contemporary Governance Models (2015), RIA (2009), etc.

Tina Jukić is a researcher and an Assistant Professor at the Faculty of Administration, University of Ljubljana. She completed her PhD at the same faculty, specializing in e-government, more precisely evaluation of e-government projects. Her current research is focused on various e-government related fields, including social media usage in public administration. She has been involved in numerous national and international research and development projects and has (co-)authored several scientific papers on development of public administration and its evaluation. In 2016, she co-chaired the European Conference on e-Government and until last year the NISPAcee e-government working group.

Mirko Vintar is Professor of E-government and Administrative Information systems at the University of Ljubljana, Faculty of Public Administration. He has more than 30 years of experience in teaching, consulting, development and research of public sector management and ICT based solutions. He has been also dean (19931995), vice-dean for research (1999-2009), founder and Head of the Institute for Informatization of Public Administration (1999-2012). He is one of co-founders of NISPAcee (Network of Institutes and Schools of Public Administration from CE Europe), member of its Steering Committee (1994-1998; 2012-2015) and NISPAcee President (2012-2014). He has been EGPA Steering Committee member (20002006). He is member of several editorial boards and published more than 200 scientific articles, books and textbooks. 


\section{References:}

Alshenqeeti, H. (2014). Interviewing as a Data Collection Method: A Critical Review. English Linguistics Research, 3(1), 39-45.

Bang, H., \& Esmark, A. (2009). Good Governance in Control Society: Reconfiguring the Political from Politics to Policy. Administrative Theory and Praxis, 31(1), 7-37.

Bevir, M. (Ed). (2011). The Sage Handbook of Governance. Los Angeles: Sage.

Buchanan, J. M., \& Tullock, G. (1962). The Calculus of Consent: Logical Foundations of Constitutional Democracy. Ann Arbor, MI: University of Michigan Press.

Burch, P., \& Heinrich, C. J. (2015). Mixed Methods for Policy Research and Program Evaluation. Singapore: Sage.

Burstein, P. (2003). The Impact of Public Opinion on Public Policy: A Review and an Agenda. Political Research Quarterly, 56(1), 29-40.

Cangiano, M. M., Curristine, T., \& Lazare, M. M. (2013). Public Financial Management and Its Emerging Architecture. Washington, DC: International Monetary Fund.

Capano, G. (2012). Policy Dynamics and Change: The Never-Ending Puzzle. In Araral, E., Fritzen S., Howlett, M., Ramesh, M., Xun W., Routledge Handbook of Public Policy (pp. 451-461). Abingdon: Routledge.

Cerny, P. G. (1990). The Changing Architecture of Politics: Structure, Agency, and the Future of the State. London: Sage.

Coglianese, C., \& Kagan, R.A. (eds.) (2007). Regulation and Regulatory Processes. Aldershot, UK: Ashgate.

Cohen, L., Manion, L., \& Morrison, K. (2007). Research Methods in Education. $6^{\text {th }}$ ed. London: Routledge.

Cohen, M. D., March, J. G., \& Olsen, J. P. (1972). A garbage can model of organizational choice. Administrative science quarterly, 1-25.

Creswell, J. W. (2014). Research Design: Qualitative, Quantitative, and Mixed Methods Approaches. London: Sage.

Damore, D. F., Bowler, S., \& Nicholson, S. P. (2012). Agenda setting by direct democracy: Comparing the initiative and the referendum. State Politics \& Policy Quarterly, 12(4), 367-393.

Easton, D. (1953). The Political System: An Inquiry into the State of Political Science. New York: Knopf.

Easton, D. (1965). A Framework for Political Analysis. Englewood Cliffs, NJ: Prentice-Hall.

EC (2017). EC-Transposition, Internal Market Scoreboard. Brussels: EC. Available online at http://ec.europa.eu/internal_market/score/index_en.htm.

Esmark, A. (2011). Systems Theory. In M. Bevir (Ed.), The Sage Handbook of Governance (pp. 91-106). London: Sage.

Fawzi, N. (2017). Beyond Policy Agenda-Setting: Political Actors' and Journalists' Perceptions of News Media Influence across All Stages of the Political Process. Information, Communication \& Society 1-17.

Gill, P., Stewart K., Treasure E. \& Chadwick B. (2008). Methods of data collection in qualitative research: interviews and focus groups. British Dental Journal, 204, 291-295.

Godec, R. (ed.) (1993). Upravni zbornik. Ljubljana: Inštitut za javno upravo pri Pravni fakulteti v Ljubljani. 
Haywood, A. (2000). Key Concepts in Politics. London: Palgrave Macmillan. Hill, M. (2009). The Public Policy Process. Harlow: Pearson Education Limited.

Howlett, M., Ramesh, M., \& Perl, A. (2003). Studying public policy: Policy cycles and policy subsystems. Oxford: Oxford University Press.

Jann, W., \& Wegrich, K. (2007). Theories of the policy cycle. In F. Fischer, G. J. Miller \& M. S. Sidney (Eds.), Handbook of public policy analysis: Theory, politics and methods (pp. 43-62). London: CRC Press.

Khandker, S. R., Koolwal, G. B., \& Samad, H. A. (2009). Handbook on impact evaluation: quantitative methods and practices. World Bank Publications.

Kooiman, J. (2003). Governing as Governance. London: Sage.

Kovač, P., (ed.) (2009). Presoja učinkov regulacije v Sloveniji. Ljubljana: Faculty of Administration.

Kovač, P. (2017). Between theoretical principles and practice in Slovene regulatory impact assessment procedures. Review of Central and East European Law, 42(2/3), 215-250, doi: 10.1163/15730352-04202003.

Kovač, P., \& Bileišis, M. (Eds.) 2017. Public Administration Reforms in Eastern European Union Member States, Post Accession Convergence and Divergence. Ljubljana, Vilnius: Mykolas Romeris University, Faculty of Administration.

Kustec Lipicer, S. (2009). Vrednotenje javnih politik. Ljubljana: Fakulteta za družbene vede.

Kvale, S. (1996). InterViews: An Introduction to Qualitative Research Interviewing. Thousand Oaks, CA: Sage.

Lavrov, A., Pirie, A. C., \& Brooke, P. J. (2006). Principles for Good Governance of Public Finance. In Background Paper to the Document Presented by the Ministry of Finance of the Russian Federation to the Meeting of Ministers of Finance of the Group of Eight, Held at St. Petersburg. St. Petersburg: Ministry of Finance of the Russian Federation.

MF (2017). Proračun; Splošno o proračunu; Klasifikacije. Ljubljana: Ministry of finance. Available at: http://www.mf.gov.si/si/delovna_podrocja/proracun/ splosno_o_proracunu/klasifikacije/\#c496

Maher, N. (2011). Financiranje proračunskih uporabnikov. Ljubljana: Zavod IRC.

Mencinger, J., \& Aristovnik, A. (2013). Fiscal Policy Stance in the European Union: The Impact of the Euro. Engineering Economics 24(1): 52-62.

Mencinger, J., Aristovnik, A., and Verbič, M. (2014). The Impact of Growing Public Debt on Economic Growth in the European Union. Amfiteatru Economic, 16(35), 403-414.

Mencinger, J., Aristovnik, A., and Verbič, M. (2015). Revisiting the Role of Public Debt in Economic Growth: The Case of OECD Countries. Engineering Economics, 26(1), 61-66.

OECD. (2015a). Country Profile: Slovenia. Available online at http://www.oecd. org/gov/regulatory-policy/Slovenia-web.pdf.

OECD. (2015b). Regulatory Policy in Perspective, A Reader's Companion to the OECD Regulatory Policy Outlook. Paris: OECD.

Olson, M. (1965). The Logic of Collective Action: Public Goods and the Theory of Groups. Cambridge, MA: Harvard University Press.

Ostrom, E. (1986). An Agenda for the Study of Institutions. Public Choice, 48(1), $3-25$. 
Ostrom, E. (1999). Institutional Rational Choice: An Assesment of the Institutional Analysis and Development Framework. In Sabatier, P. (Ed.), Theories of the Policy Process. Theoretical Lenses of on Public Policy (pp. 35-71). Cambridge, MA: Westview Press.

Ostrom, E. (2011). Background on the Institutional Analysis and Development Framework. The Policy Studies Journal, 39(1), 7-27.

Parsons, W. (1995). Public Policy: An Introduction to the Theory and Practice of Policy Analysis. Cheltenham, UK: Edward Elgar.

Princen, S. (2007). Agenda-Setting in the European Union: A Theoretical Exploration and Agenda for Research. Journal of European Public Policy, 14(1), 21-38.

Raadschelders, J. C. N. (2011). Public Administration: Interdisciplinary Study of Government. Oxford: Oxford University Press.

Radaelli, C. M., \& De Francesco, F. (2007). Regulatory Quality in Europe: Concepts, Measures and Policy Processes. Manchester: Manchester University Press.

Sabatier, P. A. (2007). Theories of the Policy Process. $2^{\text {nd }}$ ed. Boulder, CO: Westview Press.

Savard, J.-F., \& Banville, R. (2012). Policy Cycles. In Encyclopedic Dictionary of Public Administration. Edited by Louis Côté and Jean-François Savard. Available online at http://www.dictionnaire.enap.ca/Dictionnaire/en/home. aspx.

Sidney, M. S. (2007). Policy Formulation. In F. Fischer, G. J. Miller \& M. S. Sidney (Eds.), Handbook of public policy analysis: Theory, politics and methods (pp. 79-88). London: CRC Press.

SIGMA. (2014). The Principles of Public Administration. Paris: OECD.

Skocpol, T. (1997). Bringing the State Back In. In Hill, M. (Ed.), The Policy Process: A Reader (pp. 126-139). London: Prentice Hall.

Stewart, J., \& Ayres, R. (2001). Systems Theory and Policy Practice: An Exploration. Policy Sciences 34(1): 79-94.

UK Essays. (2013). Strengths and Weaknesses of Policy Cycles Politics Essay. Available online at https://www.ukessays.com/essays/politics/strengths-andweaknesses-of-policy-cycles-politics-essay.php?cref=1.

Vedung, E. (2008). Public Policy and Program Evaluation. New Brunswick, NJ: Transaction.

von Raggamby, A., \& Rubik, F. (Eds.). (2012). Sustainable Development, Evaluation and Policy-Making: Theory, Practise and Quality Assurance. Edward Elgar Publishing.

Wheelan, C. J. (2011). Introduction to Public Policy. New York: W. W. Norton \& Company.

Yin, R. K. (2009). Case Study Research: Design and Methods. Thousand Oaks, CA: Sage. 


\section{POVZETEK}

\subsection{Izvirni znanstveni članek}

\section{Oblikovanje in izvrševanje javnih politik v Sloveniji}

Oblikovanje in izvrševanje javnih politik je kompleksen proces, zato naj bi odločevalci spremljali vse faze tega cikla na posamičnem področju politik. Pri tem pa se odpira vprašanje celovite integracije različnih področij in korakov oblikovanja politik, kot so določanje ciljev, predhodna evalvacija, oblikovanje alternativ, odločanje, izvrševanje in naknadna evalvacija posameznih politik, tako sektorskih kot celo horizontalnih. Zato je pomembno preučevati in razumeti razloge, zakaj posamična država, kot je Slovenija, ne izkorišča vseh potencialnih vidikov izvajanja navedenih aktivnosti na sistematičen in medsebojno skladen način. Članek analizira slovenske prakse pri oblikovanju politik na temelju poglobljene empirične študije ključnih nosilcev javnih politik in odločevalcev. Nadalje avtorji opredelijo poglavitne dejavnike uspeha, ki pripomorejo k razvoju javnih politik, programov in projektov v Sloveniji. Rezultati kažejo, da predvsem manjka profesionalna odločevalska enota, ki bi v posameznih resorjih celovito spremljala proces, prav tako pa se pogosto ne izvaja ex-post evalvacija. Sklepno se zato ugotavlja potreba po sistematičnem pristopu k oblikovanju javnih politik, ki bi povezal različne aktivnosti oblasti, epistemološke skupnosti in javnosti v večnivojski model dobrega javnega upravljanja.

Ključne besede: javne politike, cikel, evalvacija, javna uprava, dobro upravljanje, Slovenija. 